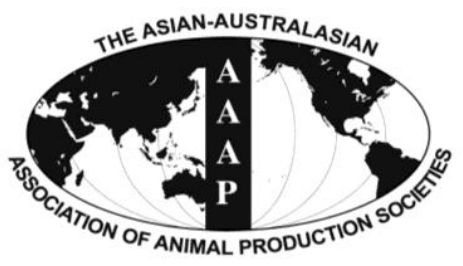

Open Access

Asian Australas. J. Anim. Sci.

Vol. 29, No. 9 : 1314-1321 September 2016

http://dx.doi.org/10.5713/ajas.15.0309

www.ajas.info

pISSN 1011-2367 elSSN 1976-5517

\title{
Dietary Phytoncide Supplementation Improved Growth Performance and Meat Quality of Finishing Pigs
}

\author{
Han Lin Li, Pin Yao Zhao, Yan Lei, Md Manik Hossain, Jungsun Kang ${ }^{1}$, and In Ho Kim* \\ Department of Animal Resource and Science, Dankook University, Cheonan 330-714, Korea
}

\begin{abstract}
We conducted this 10-wk experiment to evaluate the effects of dietary phytoncide, Korean pine extract as phytogenic feed additive (PFA), on growth performance, blood characteristics, and meat quality in finishing pigs. A total of 160 pigs ([Landrace $\times$ Yorkshire $] \times$ Duroc, body weight $(\mathrm{BW})=58.2 \pm 1.0 \mathrm{~kg}$ ) were randomly allocated into 1 of 4 treatments according to their $\mathrm{BW}$ and sex, 10 replicate pens per treatment with 4 pigs per pen were used ( 2 barrows and 2 gilts). Dietary treatments were: CON, control diet; PT2, CON+0.02\% PFA; PT4, CON+0.04\% PFA; PT6, CON+0.06\% PFA. Overall, average daily gain (ADG) was higher in PT4 $(\mathrm{p}<0.05)$ than in PT6, average daily feed intake (ADFI) was lower in PT6 than in CON $(\mathrm{p}<0.05)$. Besides ADFI decreased linearly $(\mathrm{p}<0.05)$ with the increased level of phytoncide and gain:feed ratio in PT4 treatment was higher $(\mathrm{p}<0.05)$ than CON treatment. During 5 to 10 weeks and overall, quadratic $(\mathrm{p}<0.05)$ effect was observed in ADG among the treatments. At the end of this experiment, pigs fed with PT4 diet had a greater $(\mathrm{p}<0.05)$ red blood cell concentration compared to the pigs fed CON diet. Water holding capacity increased linearly $(\mathrm{p}<0.05)$ with the increased level of phytoncide supplementation. Moreover, firmness, redness, yellowness, and drip loss at day 3 decreased linearly $(\mathrm{p}<0.05)$ with the increase in the level of phytoncide supplementation. In conclusion, inclusion of phytoncide could enhance growth performance without any adverse effects on meat quality in finishing pigs. (Key Words: Blood Profile, Finishing Pig, Growth Performance, Meat Quality, Phytoncide)
\end{abstract}

\section{INTRODUCTION}

Long-term storage of animal feed in high humidity and high temperature condition is a major problem of livestock farm production and management, because nutrients in feed can be decomposed by harmful microorganisms. For example, Aspergillus and other fungi may produce toxins such as aflatoxins, while pathogenic bacteria, such as Salmonella enteritidis and Escherichia coli, present in feed or feedstuffs for animal consumption. All of these can be dangerous for animal health (Cole and Cox, 1981). The diet of pig consists mainly of cereal grains, which often easily contaminated with aflatoxin-producing molds. It is reported that pigs to be one of the most sensitive animals to the effects of aflatoxin (Shi et al., 2005). Thus, aflatoxincontaminated feed is a serious threat to the swine industry.

\footnotetext{
* Corresponding Author: In Ho Kim. Tel: +82-41-550-3652, Fax: +82-41-565-2949, E-mail: inhokim@dankook.ac.kr

${ }^{1}$ Genebiotech. Co. Ltd., Seoul 06774, Korea.

Submitted Apr. 8, 2015; Revised Sept. 10, 2015; Accepted Dec. 1, 2015
}

Phytoncide are natural volatile compounds emitted by trees and plants as a protective mechanism against harmful insects, animals, and microorganisms. Trees and plants synthesize phytoncide as secondary metabolites of photosynthesis. Phytoncide are enriched in terpenoids, phenylpropanoids, and alkaloids; major ingredients include monoterpenoids, including $\alpha$-pinene, careen, and myrcene (Durham et al., 1994; Nose, 2000; Oikawa, 2005). As a mean of suppressing activity of microorganisms, such as bacteria and fungi, relatively large amounts of phytoncide were released by Korean pines and other conifers into the environment (Pečiulytė et al., 2010). The suppressive activity relies on essential oil, terpenoids, alkaloid, and phenylpropanoids of phytoncide (Durham et al., 1994). Due to them, phytogenic feed additive (PFA) have a potential capacity to intercalate into the bacterial membrane, disintegrate the membrane, and cause ion leakage (Burt, 2004; Hashemi and Davoodi, 2010). Moreover, this can interfere with regulatory networks of signal transduction and gene expression in aflatoxin biosynthesis, or by 
blocking the enzymatic activity of a biosynthetic enzyme (Holmes et al., 2008).

These previous findings suggested that phytoncide as a potential feed additive. In support of this, one study described the antioxidative potential of phytoncide and their effects in reducing oxidative stress responses in strokeprone spontaneously hypertensive rats (Kawakami et al., 2004). Moreover, stress level was known to have negative correlation with meat quality (Terlouw, 2005). According to these previous studies, we could hypothesis that dietary phytoncide supplementation may help to improve growth performance and meat quality in finishing pigs. However, the effect of dietary phytoncide supplementation in finishing pigs has not yet been investigated. Thus, this study was conducted to determine the effect of dietary phytoncide supplementation on growing performance, blood characteristics, and meat quality in finishing pigs.

\section{MATERIALS AND METHODS}

\section{Preparation of phytoncide and experimental animals}

The phytoncide (PHYLUS Company, Seoul, Korea) used in this study was extracted from Korean pine. It contained $20 \%$ active substance (flavonoid, phenolic compounds, alkaloid, tannin, terpene, saponin) and $80 \%$ carrier (dextrin). About $40 \%$ of active substance were essential oils. The experimental protocol was approved by the animal care and use committee of Dankook University (Ethics Approval Number: DK-1152).

A total of 160 finishing pigs ([LandracexYorkshire]x Duroc, body weight $[\mathrm{BW}]=58.2 \pm 1.0 \mathrm{~kg}$ ) were randomly allocated into 1 of 4 treatments according to their BW and sex. Ten replicate pens per treatment with 4 pigs per pen were used ( 2 barrows and 2 gilts). Dietary treatments included: $\mathrm{CON}$, control diet; PT2, $\mathrm{CON}+0.02 \%$ PFA; PT4, $\mathrm{CON}+0.04 \%$ PFA; PT6, CON+0.06\% PFA. All pigs were housed in pens $(1.8 \times 1.8 \mathrm{~m})$ with a self-feeder and nipple drinker that allowed pig ad libitum access to feed and water throughout the whole experimental period. Temperature was maintained at $24^{\circ} \mathrm{C}$ to $26^{\circ} \mathrm{C}$. Dietary phytoncide was supplemented in diets by replacing the same amount of corn in our current study. As showed in Table 1, all diets used in present study were formulated to meet or little exceed the nutrient recommendations of NRC (2012). Diets were formulated to the same concentrations of lysine, crude protein (CP), metabolizable energy, calcium, and phosphorus (Table 1).

\section{Sampling and measurements}

BW and feed intake were measured at the start of experiment and at the end of 5 and $10 \mathrm{wk}$ to calculate average daily gain (ADG), average daily feed intake (ADFI) and gain:feed. Samples of diets were analyzed for
Table 1. Formula and chemical composition of experimental diet (as-fed basis)

\begin{tabular}{|c|c|}
\hline Items & \\
\hline \multicolumn{2}{|l|}{ Ingredients (\%) } \\
\hline Corn & 67.81 \\
\hline Soybean meal ( $48 \%)$ & 17.88 \\
\hline Rice bran & 5.00 \\
\hline Molasses, sugar beets & 5.00 \\
\hline Tallow & 2.00 \\
\hline Dicalcium phosphate & 0.75 \\
\hline Calcium carbonate & 0.94 \\
\hline L-Lys. $\mathrm{HCl}(78 \%)$ & 0.30 \\
\hline Salt & 0.15 \\
\hline Vit-perimix* & 0.07 \\
\hline Min-premix* & 0.10 \\
\hline \multicolumn{2}{|l|}{ Calculated nutrient composition } \\
\hline Metabolizable energy (kcal/kg) & 3,308 \\
\hline Crude protein $(\%)$ & 15.63 \\
\hline Lysine (\%) & 0.97 \\
\hline Calcium $(\%)$ & 0.60 \\
\hline Phosphorus (\%) & 0.56 \\
\hline \multicolumn{2}{|l|}{ Analyzed nutrient composition } \\
\hline Metabolizable energy (kcal/kg) & 3,301 \\
\hline Crude protein $(\%)$ & 15.50 \\
\hline Lysine (\%) & 0.968 \\
\hline Calcium (\%) & 0.59 \\
\hline Phosphorus (\%) & 0.52 \\
\hline Crude fat $(\%)$ & 5.33 \\
\hline Crude fiber $(\%)$ & 4.14 \\
\hline \multicolumn{2}{|c|}{$\begin{array}{l}\text { * Provided per kg of complete diet: } 4,000 \mathrm{IU} \text { of vitamin A; } 800 \mathrm{IU} \text { of } \\
\text { vitamin } \mathrm{D}_{3} ; 17 \mathrm{IU} \text { of vitamin } \mathrm{E} ; 2 \mathrm{mg} \text { of vitamin K; } 4 \mathrm{mg} \text { of vitamin } \mathrm{B}_{2} \\
1 \mathrm{mg} \text { of vitamin } \mathrm{B}_{6} ; 16 \mu \mathrm{g} \text { of vitamin } \mathrm{B}_{12} ; 11 \mathrm{mg} \text { of pantothenic acid; } 20 \\
\mathrm{mg} \text { of niacin; } 0.02 \mathrm{mg} \text { of biotin; } 220 \mathrm{mg} \text { of } \mathrm{Cu}\left(\mathrm{CuSO}_{4} 5 \mathrm{H}_{2} \mathrm{O}\right) ; 175 \mathrm{mg} \text { of } \\
\mathrm{Fe}\left(\mathrm{FeSO}_{4} \mathrm{H}_{2} \mathrm{O}\right) ; 191 \mathrm{mg} \text { of } \mathrm{Zn}\left(\mathrm{ZnSO}_{4} \mathrm{H}_{2} \mathrm{O}\right) ; 89 \mathrm{mg} \text { of } \mathrm{Mn}(\mathrm{MnO}) ; 0.3 \\
\mathrm{mg} \text { of } \mathrm{I}\left(\mathrm{CaI}_{2}\right) ; 0.5 \mathrm{mg} \text { of } \mathrm{Co}\left(\mathrm{CoSO}_{4} 7 \mathrm{H}_{2} \mathrm{O}\right) ; 0.3 \mathrm{mg} \text { of Se }\left(\mathrm{Na}_{2} \mathrm{SeO}^{2}\right. \\
\left.5 \mathrm{H}_{2} \mathrm{O}\right) \text {. }\end{array}$} \\
\hline
\end{tabular}

CP (procedure 984.13; AOAC, 2006), calcium (procedure 968.08; AOAC, 2006), phosphorus (procedure 946.06; AOAC, 2006), and crude fiber (procedure 978.10; AOAC, 2006). Crude fat were determined according to the method of Thiex et al. (2003) and Kjeldahl $\mathrm{N}$ was determined according to the method of Thiex et al. (2002). The concentrations of neutral detergent fiber and acid detergent fiber were determined according to the method of Van Soest et al. (1991). The concentration of crude fiber was analyzed using heat-stable $\alpha$-amylase and sodium sulfite without correction for insoluble ash as adapted for an Ankom Fiber Analyzer (Ankom Technology, Macedon, NY, USA). Samples of diets were analyzed for metabolizable energy via an adiabatic oxygen bomb calorimeter (Parr Instruments Co., Moline, IL, USA).

Blood samples were collected via jugular vein into either 5-mL vacuum or 5-mL K3EDTA vacuum tube (Becton Dickinson Vacutainer Systems, Franklin Lakes, NJ, 
USA) from 2 pigs each pen on the initial and final day of the experimental period. Concentrations of red blood cell (RBC) and white blood cell (WBC) in whole blood samples were measured using the automatic blood analyzer (ADVIA 120, Bayer, Tarrytown, NY, USA). Serum samples were centrifuged $(3,000 \times \mathrm{g})$ for $15 \mathrm{~min}$ at $4^{\circ} \mathrm{C}$, and then concentrations of cortisol was measured using the automatic biochemistry analyzer (HITACHI 747, Tokyo, Japan).

At the end of the experiment, 10 pigs per treatment (1 pig per pen with a BW of pen average) were transported to the abattoir for slaughter. The carcasses were placed in a conventional chiller at $4^{\circ} \mathrm{C}$. After $24 \mathrm{~h}$ chill period, carcasses were fabricated into primal cuts. Meat samples, which included lean and fat, were taken via perpendicular cut loins into 2-cm-thick chop beginning from the 10th and 11 th ribs region. Back fat thickness was measuring midline fat thickness by using a real-time ultrasound instrument (Piglot 105, SFK Technology, Herlev, Denmark) according to method of Wang et al. (2009). The $\mathrm{pH}$ of longissimus muscle (LM) was measured in $24 \mathrm{H}$ post-mortem with an insertion of glass electrode (Radiometer, Lyon, France) connected to a $\mathrm{pH}$-meter (NWKbinar $\mathrm{pH}, \mathrm{K}-21$, Landsberg, Germany). The electrode was calibrated at $20^{\circ} \mathrm{C}$ in buffers at $\mathrm{pH}$ value of 4.00 and 7.00. Surface LM color (Minolta $\left.\mathrm{L}^{*}, \mathrm{a}^{*}, \mathrm{~b}^{*}\right)$ was measured in triplicate on a freshly-cut surface with a Minolta Chromameter (Minolta CR 301, Tokyo, Japan). The water holding capacity (WHC) was measured according to the methods of Kauffman et al. (1986). In brief, $0.2 \mathrm{~g}$ sample was pressed at 3,000 psi for 3 min on 125 -mm-diameter filter paper. The areas of the pressed sample and expressed moisture were delineated and then determined with a digitizing area-line sensor (MT-10S; M.T. Precision Co. Ltd., 123 Tokyo, Japan). A ratio of water: meat areas was calculated, giving a measure of WHC (the smaller ratio indicate the higher the WHC). The proportion of LM acceptable for Pork Composition and Quality Assessment Procedures (NPPC, 1991) was determined via the selection of LM with acceptable color, firmness, and marbling (all measures 3 or greater, based on a scale of 1 to 5; NPPC, 1991). Drip loss was measured using approximately $2 \mathrm{~g}$ of meat sample according to the plastic bag method, which was described by Honikel (1998).

\section{Statistical analyses}

For current experiment, effects of treatment $(0,0.02 \%$, $0.04 \%, 0.06 \%$ phytoncide) were analyzed by analysis of variance (ANOVA) using the Mixed Models procedure of SAS (SAS Institute, 2003). The pen was used as the experimental unit for growth performance analysis, while data of blood profile and meat quality were based on individual pigs. The initial BW was used as a covariate for ADFI and ADG, and initial values were used as a covariate for blood profile. The complete model of blood profiles included the main effects of treatment, litter and time, and the treatment $\times$ time interaction. Differences among treatment means were determined using the Tukey's multiple range test. Probabilities less than 0.05 were considered to be significant. After ANOVA analysis, linear and quadratic polynomial contrasts were performed to determine the effects of different level of phytoncide $(0.02 \%, 0.04 \%$, and $0.06 \%)$ in the diet.

\section{RESULTS}

\section{Growth performance}

During 0 to 5 weeks, pigs fed the PT4 diet had a greater $(\mathrm{p}<0.05)$ ADG than pigs fed the PT6 diet (Table 2). From 5 to 10 weeks, pigs fed the PT4 diet had a greater $\mathrm{G}: \mathrm{F}$ $(p<0.05)$ than pigs fed the CON diet. During the entire experimental period, ADG was increased with supplementation with $0.04 \%$ phytoncide $(\mathrm{p}<0.05)$ compared with the inclusion of $0.06 \%$ phytoncide. Furthermore, ADFI in the PT6 group was lower $(\mathrm{p}<0.05)$ than that in the CON group, and G:F in PT4 treatment was higher $(\mathrm{p}<0.05)$ than with CON.

Moreover, throughout the experimental period, the ADFI decreased linearly $(\mathrm{p}<0.05)$ with the increased level of phytoncide, and a significant quadratic effect $(\mathrm{p}<0.05)$ was observed in G:F among treatments. During 5 to 10 weeks and overall, a significant quadratic effect $(\mathrm{p}<0.05)$ was observed in ADG among treatments.

\section{Blood profiles}

Blood profiles are presented in Table 3. At the end of the experiment, pigs fed the PT4 diet had a higher $(\mathrm{p}<0.05)$ RBC concentration than the pigs fed the CON diet. Also, the cortisol concentration was decreased $(\mathrm{p}<0.05)$ with PT2 and PT4 treatment versus the CON treatment. Time effect was observed in cortisol and WBC, while no treatment $\times$ time interaction effect was observed. Moreover, a significant quadratic effect was observed in cortisol, RBC, and WBC among treatments.

\section{Meat quality}

As shown in Table 4, supplementation with $0.02 \%$ and $0.06 \%$ phytoncide increased $(\mathrm{p}<0.05)$ the sensory color compared with CON treatment, and inclusion of $0.04 \%$ and $0.06 \%$ phytoncide decreased $(\mathrm{p}<0.05)$ sensory firmness versus CON treatment. WHC in PT6 was higher $(\mathrm{p}<0.05)$ than that in the PT2 and CON treatments. No difference $(\mathrm{p}<0.05)$ was observed in loin muscle area, $\mathrm{pH}$, meat color, or drip loss $(\mathrm{p}>0.05)$. Moreover, firmness, redness, yellowness, and drip loss at day 3 decreased linearly ( $\mathrm{p}<$ $0.05)$ with the increase in the level of phytoncide 
Table 2. Effect of phytoncide on growth performance in finishing pigs

\begin{tabular}{|c|c|c|c|c|c|c|c|c|}
\hline \multirow{2}{*}{ Item } & \multirow{2}{*}{$\mathrm{CON}^{1}$} & \multirow{2}{*}{$\mathrm{PT} 2^{1}$} & \multirow{2}{*}{$\mathrm{PT} 4^{1}$} & \multirow{2}{*}{$\mathrm{PT}^{1}$} & \multirow{2}{*}{$\mathrm{SE}^{2}$} & \multicolumn{3}{|c|}{ p-value } \\
\hline & & & & & & Treatment & Linear & Quadratic \\
\hline \multicolumn{9}{|l|}{ BW (kg) } \\
\hline Initial $^{3}$ & 58.2 & 58.3 & 58.2 & 58.2 & 0.1 & 0.80 & 0.01 & 0.84 \\
\hline Final $^{3}$ & $116.9^{b}$ & $119.2^{\mathrm{ab}}$ & $123.0^{\mathrm{a}}$ & $114.6^{\mathrm{b}}$ & 2.9 & 0.01 & 0.70 & 0.04 \\
\hline \multicolumn{9}{|l|}{0 to 5 week } \\
\hline $\operatorname{ADG}(\mathrm{g})$ & $886^{\mathrm{ab}}$ & $838^{\mathrm{ab}}$ & $917^{\mathrm{a}}$ & $786^{\mathrm{b}}$ & 34.4 & $<0.01$ & 0.63 & 0.34 \\
\hline ADFI (g) & 2,280 & 2,112 & 2,135 & 2,077 & 65.5 & 0.43 & 0.04 & 0.67 \\
\hline Gain:feed & 0.389 & 0.397 & 0.430 & 0.378 & 0.022 & 0.76 & 0.72 & 0.03 \\
\hline \multicolumn{9}{|l|}{5 to 10 week } \\
\hline $\mathrm{ADG}(\mathrm{g})$ & 792 & 902 & 934 & 862 & 49.3 & 0.11 & 0.82 & 0.01 \\
\hline ADFI (g) & 2,829 & 2,785 & 2,658 & 2,520 & 103.4 & 0.69 & $<0.001$ & 0.55 \\
\hline Gain:feed & $0.280^{\mathrm{b}}$ & $0.324^{\mathrm{ab}}$ & $0.351^{\mathrm{a}}$ & $0.342^{\mathrm{ab}}$ & 0.014 & $<0.01$ & 0.24 & $<0.001$ \\
\hline \multicolumn{9}{|l|}{0 to 10 week } \\
\hline $\operatorname{ADG}(\mathrm{g})$ & $839^{\mathrm{ab}}$ & $870^{\mathrm{ab}}$ & $925^{\mathrm{a}}$ & $806^{\mathrm{b}}$ & 28.8 & 0.03 & 0.47 & $<0.001$ \\
\hline ADFI (g) & $2,555^{\mathrm{a}}$ & $2,448^{\mathrm{ab}}$ & $2,397^{\mathrm{ab}}$ & $2,299^{\mathrm{b}}$ & 66.3 & 0.05 & $<0.001$ & 0.81 \\
\hline Gain:feed & $0.328^{\mathrm{b}}$ & $0.355^{\mathrm{ab}}$ & $0.386^{\mathrm{a}}$ & $0.351^{\mathrm{ab}}$ & 0.015 & 0.01 & 0.39 & $<0.001$ \\
\hline
\end{tabular}

SE, standard error; BW, body weight; ADG, average daily gain; ADFI, average daily feed intake.

${ }^{1} \mathrm{CON}$, basal diet; $\mathrm{P} 2$, basal diet $+0.02 \%$ phytoncide; $\mathrm{P} 4$, basal diet $+0.04 \%$ phytoncide; $\mathrm{P} 6$, basal diet $+0.06 \%$ phytoncide.

${ }^{2}$ Each mean represents 40 observations per treatment.

${ }^{3}$ Initial, the 1st day of experiment; final, the last day (d 70) of experiment.

${ }^{\mathrm{a}, \mathrm{b}}$ Means in the same row with different superscripts differ $(\mathrm{p}<0.05)$, initial BW was used as a covariate.

supplementation, and WHC increased linearly $(\mathrm{p}<0.05)$ with the increased level of phytoncide supplementation.

\section{DISCUSSION}

As an alternative feeding strategy to growth promoters, PFA have received considerable attentions recently. Various trials have demonstrated positive effects of PFA in swine and poultry (Wang et al., 2008; Windisch et al., 2008; Van Krimpen et al., 2010). Wang et al. (2008) reported that $0.04 \%$ dietary phytogenic feed additive, which was made of essential oils, flavonoids, pungent substances, and mucliages, did not affect the ADFI of lactating sows. Whereas, Zhang et al. (2012) observed that weaning pigs fed with $0.2 \%$ phytoncide showed a greater G:F ratio. Moreover, Yan et al. (2010) reported that $0.01 \%$ essential oil used as PFA increased ADG and G:F at different nutrient densities in pigs. Consistent with these previous studies, our study demonstrated that $0.04 \%$ phytoncide increased ADG and $\mathrm{G}: \mathrm{F}$ ratio in finishing pigs. Essential oils, as a main content of phytogenic additive, may have beneficial effects such as antiviral and antimicrobial activity, and are capable of stimulating enzyme activity and immune function in livestock (Williams and Losa, 2001; Yan et al., 2010). Also, positive of essential oils on digestive system and stimulating effect on the output of digestive enzymes from the pancreas, gut mucosa, and increase bile flow have been reported (Jamroz and Kamel, 2002; Jamroz et al., 2005;

Table 3. Effect of phytoncide on blood profile in finishing pigs

\begin{tabular}{|c|c|c|c|c|c|c|c|c|c|c|}
\hline \multirow{2}{*}{ Item } & \multirow{2}{*}{$\mathrm{CON}^{1}$} & \multirow{2}{*}{$\mathrm{PT} 2^{1}$} & \multirow{2}{*}{$\mathrm{PT} 4^{1}$} & \multirow{2}{*}{ PT6 $^{1}$} & \multirow{2}{*}{$\mathrm{SE}^{2}$} & \multicolumn{5}{|c|}{ p-value } \\
\hline & & & & & & Treatment & Time & Treatmentxtime & Linear & Quadratic \\
\hline \multicolumn{11}{|c|}{ Cortisol $(\mu \mathrm{g} / \mathrm{dL})$} \\
\hline Initial $^{3}$ & 1.20 & 1.20 & 1.13 & 1.00 & 0.24 & $<0.01$ & $<0.01$ & 0.57 & 0.08 & 0.57 \\
\hline Final $^{3}$ & $2.20^{\mathrm{a}}$ & $1.00^{\mathrm{c}}$ & $1.20^{\mathrm{bc}}$ & $2.00^{\mathrm{ab}}$ & 0.27 & & & & 0.82 & 0.02 \\
\hline \multicolumn{11}{|c|}{ Red blood cell $\left(10^{6} / \mu \mathrm{L}\right)$} \\
\hline Initial $^{3}$ & 6.59 & 6.43 & 6.64 & 6.82 & 0.34 & $<0.01$ & 0.36 & 0.44 & 0.63 & 0.46 \\
\hline Final $^{3}$ & $4.67^{\mathrm{b}}$ & $6.63^{\mathrm{ab}}$ & $7.15^{\mathrm{a}}$ & $6.54^{\mathrm{ab}}$ & 0.31 & & & & 0.71 & $<0.001$ \\
\hline \multicolumn{11}{|c|}{ White blood cell $\left(10^{3} / \mu \mathrm{L}\right)$} \\
\hline Initial $^{3}$ & 22.69 & 21.68 & 22.08 & 21.77 & 2.47 & 0.09 & 0.03 & 0.64 & 0.27 & 0.14 \\
\hline Final $^{3}$ & 19.17 & 19.47 & 22.10 & 17.89 & 1.42 & & & & 0.52 & 0.01 \\
\hline
\end{tabular}

\footnotetext{
${ }^{1} \mathrm{CON}$, basal diet; PT2, basal diet+0.02\% phytoncide; PT4, basal diet $+0.04 \%$ phytoncide; PT6, basal diet $+0.06 \%$ phytoncide.

${ }^{2}$ Standard error. Each mean represents 20 observations per treatment.

${ }^{3}$ Initial, the 1st day of experiment; final, the last day (d 70) of experiment.

${ }^{a, b}$ Means in the same row with different superscripts differ $(p<0.05)$.
} 
Table 4. Effect of phytoncide on meat quality in finishing pigs

\begin{tabular}{|c|c|c|c|c|c|c|c|c|}
\hline \multirow{2}{*}{ Item } & \multirow{2}{*}{$\mathrm{CON}^{1}$} & \multirow{2}{*}{$\mathrm{PT} 2^{1}$} & \multirow{2}{*}{$\mathrm{PT} 4^{1}$} & \multirow{2}{*}{$\mathrm{PT}^{1}$} & \multirow{2}{*}{$\mathrm{SE}^{2}$} & \multicolumn{3}{|c|}{$\mathrm{p}$-value } \\
\hline & & & & & & Treatment & Linear & Quadratic \\
\hline \multicolumn{9}{|l|}{ Sensory evaluation } \\
\hline Color & $1.88^{\mathrm{b}}$ & $2.17^{\mathrm{a}}$ & $1.96^{\mathrm{ab}}$ & $2.21^{\mathrm{a}}$ & 0.077 & 0.05 & 0.14 & 0.57 \\
\hline Marbling & 1.79 & 1.63 & 1.75 & 1.92 & 0.134 & 0.12 & 0.40 & 0.03 \\
\hline Firmness & $2.25^{\mathrm{a}}$ & $1.96^{\mathrm{ab}}$ & $1.92^{\mathrm{b}}$ & $1.92^{\mathrm{b}}$ & 0.10 & 0.02 & 0.05 & 0.11 \\
\hline Lean meat area $\left(\mathrm{cm}^{2}\right)$ & 44.78 & 46.84 & 42.52 & 44.21 & 1.97 & 0.23 & 0.23 & 0.42 \\
\hline $\mathrm{pH}$ & 5.24 & 5.25 & 5.32 & 5.23 & 0.04 & 0.71 & 0.07 & 0.10 \\
\hline \multicolumn{9}{|l|}{ Meat color } \\
\hline Lightness (L*) & 55.98 & 56.25 & 57.33 & 56.45 & 1.13 & 0.57 & 0.14 & 0.29 \\
\hline Redness $\left(a^{*}\right)$ & 21.08 & 20.05 & 18.38 & 17.08 & 1.13 & 0.12 & 0.01 & 0.57 \\
\hline Yellowness (b*) & 10.60 & 9.45 & 8.83 & 8.53 & 0.72 & 0.26 & 0.04 & 0.37 \\
\hline Water holding capacity (WHC, \%) & $56.94^{\mathrm{c}}$ & $64.73^{\mathrm{b}}$ & $64.93^{\mathrm{ab}}$ & $68.18^{\mathrm{a}}$ & 1.03 & $<0.01$ & 0.02 & 0.76 \\
\hline \multicolumn{9}{|l|}{ Drip loss $(\%)$} \\
\hline $3 \mathrm{~d}$ & 10.66 & 10.34 & 9.21 & 8.65 & 1.37 & 0.35 & 0.03 & 0.39 \\
\hline $6 \mathrm{~d}$ & 11.82 & 13.53 & 11.72 & 10.26 & 1.65 & 0.40 & 0.17 & 0.09 \\
\hline
\end{tabular}

${ }^{1}$ CON, basal diet; PT2, basal diet $+0.02 \%$ phytoncide; PT4, basal diet $+0.04 \%$ phytoncide; PT6, basal diet $+0.06 \%$ phytoncide.

${ }^{2}$ Standard error. Each mean represents 10 observations per treatment.

${ }^{a, b, c}$ Means in the same row with different superscripts differ $(\mathrm{p}<0.05)$.

Jang et al., 2007), which may explain the improvement of growth performance of pigs in our present experiment. Also, specific capabilities of phytogenic compounds is to enhance the activities of digestive enzymes (bile, pancreatic lipase and amylase etc.) and nutrient absorption (Windisch et al., 2008), which may be another explanation for our results.

The quality of plant materials, selection of particular plants, and forms for administration (i.e., extracts, oils, and dried herbs) also influence their effects on pig performance. As mentioned above, the active substances in phytoncide have a potential capacity to intercalate into the bacterial membrane, disintegrate the membrane, and cause ion leakage, it means that PFA could inhibit the biosynthesis or expression of aflatoxin, or block the enzymatic activity of a biosynthetic enzyme, which including superoxide dismutase, xanthine oxidase, glutathione peroxidase, and two microsomal reductases (Burt, 2004; Holmes et al., 2008; Hashemi and Davoodi, 2010). Those may be the reason why it could promote growth performance of pigs by protecting feed quality. However, inconsistent results have been obtained regarding the effects of PFA on ADFI in animals. Yan et al. (2011a) noted that $1 \mathrm{~g} / \mathrm{kg}$ herbal extract (Houttuynia cordata or Taraxacum officinale) used as PFA increased ADFI during a 10-week trial. Wang et al. (2007) and Wenk et al. (2003) reported that herbs used as PFA could improve the flavor and palatability of feed, subsequently increasing the total feed intake and growth performance. Yan et al. (2010) demonstrated that $0.01 \%$ essential oil, including thyme, rosemary, oreganum extracts, and kaolin covered by starch had a tendency to lower ADFI. One reasonable explanation for the lower ADFI might be the tranquilizing effect of PFA, which reduced the spontaneous physical activity of the pigs. Physical activity influences heat production, which can cause additional expenditure of energy (Wang et al., 2007). Moreover, pungent substances of some plants (e.g., capsaicin, allitricin, and piperine), which are the active components of PFA, may reduce the palatability of feed and restrict their use for animal feeding purpose (Zhong et al., 2011). In line with our study, previous studies also showed dose-related depressions of palatability of pigs fed with essential oils from the herbs thyme and oregano, as well as from caraway and fennel (Jugl-Chizzola et al., 2006; Schone et al., 2006). Therefore, according to these previous studies the elevate effect of essential may depressed as pungent substances concentration increased.

Czech et al. (2009) reported that pigs fed a mixture with a supplement of $8 \mathrm{~g} / \mathrm{kg}$ herbal mixture during the whole fattening period were characterized by a significantly higher value of red blood cell system indices, including serotonin, hemoglobin, and RBC. Yan et al. (2011b) confirmed this result, describing increased $\mathrm{RBC}$ concentrations in pigs fed 250 or $500 \mathrm{mg} / \mathrm{kg}$ of herb extract mixture. Pungent substances (e.g. garlic, black pepper, and chilli), the active components of PFA, could activate blood circulation and metabolic processes (Rodas, 2006). Consistent with that, Iranloye (2002) showed that feeding rats with $200 \mathrm{mg} / \mathrm{kg}$ garlic juice daily increased the RBC and WBC. Moreover, Wang et al. (2008) observed that RBC and WBC were increased significantly with PFA treatment. Phytoncide had also been shown to reduce stress responses by lowering stress-related hormones (Kawakami et al., 2004). Collectively, these findings indicate that phytoncide as PFA can increase blood circulation, metabolic processes, and the 
immune system of pigs.

Phytoncide can reduce stress responses in stroke-prone spontaneously hypertensive rats (Kawakami et al., 2004). Nam and Uhm (2008) documented that phytoncide decreased serum cortisol levels significantly in college students. Psychological stress affects immune function and predicts infectious disease susceptibility in humans and animals (Marsland et al., 2002). Plant extracts could stimulate $\mathrm{T}$ cell-mediated immune responses (Islam et al., 2004). Additionally, flavonoids, one bioactive substance within phytoncide, exhibit inhibitory effects against multiple viruses and improve immunity (Critchfield et al., 1996). In line with previous studies, the concentration of stress-related hormone, cortisol, was reduced significantly with phytoncide supplementation in our present study, indicating that stress was reduced and immunity was enhanced with phytoncide supplementation (Koopmans et al., 2005). In contrast, the effects of PFA on blood profiles have been inconsistent, which might be attributable to interactions between PFA and different feed formulae.

Unacceptable water-holding capacity costs the meat industry millions of dollars annually. Product weight losses due to purge can average as much as $1 \%$ to $3 \%$ in fresh retail cuts (Offer and Knight, 1988a) and can be as high at $10 \%$ in pale soft exudative products (Melody et al., 2004). In addition to the loss of salable weight, purge loss also entails the loss of a significant amount of protein (Offer and Knight, 1988b). On average, purge can contain approximately $112 \mathrm{mg}$ of protein per $\mathrm{mL}$ of fluid, mostly water-soluble, sarcoplasmic proteins (Savage et al., 1990). In the current study, phytoncide treatments showed beneficial effects on WHC. It is clear that early postmortem events including the rate and extent of $\mathrm{pH}$ decline, proteolysis, and even protein oxidation, are key to influencing the ability of meat to retain moisture (HuffLonergan and Lonergan, 2005). Consequently, the antioxidant activities of phytoncide may be a factor causing the higher WHC. Moreover, cortisol was known to increase associated with stress, and stress would decrease meat quality (Terlouw, 2005), in line with our study, cortisol decreased and meat quality increased with $0.04 \%$ of phytoncide inclusion.

In conclusion, our results indicate that Korean pine extract supplementation can promote growth performance and elevate meat quality. So that dietary Korean pine extract, phytoncide, could be considered as a potential natural growth promoter in finishing pigs.

\section{CONFLICT OF INTEREST}

We certify that there is no conflict of interest with any financial organization regarding the material discussed in the manuscript.

\section{ACKNOWLEDGMENTS}

This work was supported by a grant from the NextGeneration BioGreen 21 Program (No. PJ01115902), Rural Development Administration, Republic of Korea.

\section{REFERENCES}

AOAC. 2006. Official Methods of Analysis. 18th edn. Association of Official Analytical Chemists, Arlington, VA, USA.

Burt, S. 2004. Essential oils: Their antibacterial properties and potential applications in foods-A review. Int. J. Food Microbiol. 94:223-253.

Cole, R. J. and R. H. Cox. 1981. Handbook of Toxic Fungal Metabolites. Academic Press, New York, USA.

Critchfield, J. W., S. T. Butera, and T. M. Folks. 1996. Inhibition of HIV activation in latently infected cells by flavonoid compounds. AIDS Res. Hum. Retroviruses 12:39-46.

Czech, A., E. Kowalczuk, and E. R. Grela. 2009. The effect of a herbal extract used in pig fattening on the animals' performance and blood components. Ann. Univ. Mariae. Curie. Sklodowska Sect. EE Zootech. 27:25-33.

Durham, D. G., X. Liu, and R. M. E. Richards. 1994. A triterpene from Rubus pinfaensis. Phytochemistry 36:1469-1472.

Hashemi, S. R. and H. Davoodi. 2010. Phytogenics as new class of feed additive in poultry industry. J. Anim. Vet. Adv. 9:22952304.

Holmes, R. A., R. S. Boston, and G. A. Payne. 2008. Diverse inhibitors of aflatoxin biosynthesis. Appl. Microbiol. Biotechnol. 78:559-572.

Honikel, K. O. 1998. Reference methods for the assessment of physical characteristics of meat. Meat Sci. 49:447-457.

Huff-Lonergan, E. and S. M. Lonergan. 2005. Mechanisms of water-holding capacity of meat: The role of postmortem biochemical and structural changes. Meat Sci. 71:194-204.

Iranloye, B. O. 2002. Effect of chronic garlic feeding on some haematological parameters. ABNF J. 5:1-2.

Islam, S. N., P. Begum, T. Ahsan, S. Huque, and M. Ahsan. 2004. Immunosuppressive and cytotoxic properties of Nigella sativa. Phytother. Res. 18:395-398.

Jamroz, D. and C. Kamel. 2002. Plant extracts enhance broiler performance. In non ruminant nutrition: Antimicrobial agents and plant extracts on immunity, health and performance J. Anim. Sci. 80 (Suppl. 1):41.

Jamroz, D., A. Wiliczkiewicz, T. Wertelecki, J. Orda, and J. Skorupinska. 2005. Use of active substances of plant origin in chicken diets based on maize and locally grown cereals. Br. Poult. Sci. 46:485-493.

Jang, I. S., Y. H. Ko, S. Y. Kang, and C. Y. Lee. 2007. Effect of commercial essential oils on growth performance, digestive enzyme activity, and intestinal microflora population in broiler chickens. Anim. Feed Sci. Technol. 134:304-315.

Jugl-Chizzola, M., E. Ungerhofer, C. Gabler, W. Hagmuller, R. Chizzola, K. Zitterl-Eglseer, and C. Franz. 2006. Testing of the palatability of Thymus vulgaris $\mathrm{L}$. and Origanum vulgare L. as flavouring feed additive for weaner pigs on the basis of a choice experiment. Berl. Munch. Tierarztl. Wochenschr. 119:238-243. 
Kauffman, R. G., G. Eikelenboom, P. G. Van der Wal, B. Engel, and M. Zaar. 1986. A comparison of methods to estimate water holding capacity in post-rigor porcine muscle. Meat Sci. 18:307-322.

Kawakami, K., M. Kawamoto, M. Nomura, H. Otani, T. Nabika, and T. Gonda. 2004. Effects of phytoncide on blood pressure under restraint stress in SHRSP. Clin. Exp. Pharmacol. Physiol. 31:S27-S28.

Koopmans, S. J., M. Ruis, R. Dekker, H. van Diepen, M. Korte, and Z. Mroz. 2005. Surplus dietary tryptophan reduces plasma cortisol and noradrenaline concentrations and enhances recovery after social stress in pigs. Physiol. Behav. 85:469-478.

Marsland, A. L., E. A. Bachen, S. Cohen, B. Rabin, and S. B. Manuck. 2002. Stress, immune reactivity and susceptibility to infectious disease. Physiol. Behav. 77:711-716.

Melody, J. L., S. M. Lonergan, L. J. Rowe, T. W. Huiatt, M. S. Mayes, and E. Huff-Lonergan. 2004. Early postmortem biochemical factors influence tenderness and water-holding capacity of three porcine muscles. J. Anim. Sci. 82:1195-1205.

Nam, E. S. and D. C. Uhm. 2008. Effects of phytoncides inhalation on serum cortisol level and life stress of college students. Korean. J. Adult. Nurs. 20:697-706.

Nose, K. 2000. Role of reactive oxygen species in the regulation of physiological functions. Biol. Pharm. Bull. 23:897-903.

NPPC (National Pork Producers Council). 1991. Procedures to Evaluate Market Hogs. 3rd edn. National Pork Producers Council, Des Moines, IA, USA.

NRC. 2012. Nutrient Requirement of Swine. 11th edn. The National Academy Press, Washington, DC, USA.

Offer, G. and P. Knight. 1988a. The structural basis of waterholding capacity in meat. Part 1: general principles and water uptake in meat processing. In Developments in Meat Science (Ed. R. Lawrie). 4th edn. Elsevier, Oxford, UK.

Offer, G. and P. Knight. 1988b. The structural basis of waterholding capacity in meat. Part 2: Drip Losses. In Developments in Meat Science (Ed. R. Lawrie). 4th edn. Elsevier, Oxford, UK.

Oikawa, S. 2005. Sequence-specific DNA damage by reactive oxygen species: Implications for carcinogenesis and aging. Environ. Health Prev. Med. 10:65-71.

Pečiulyte, D., I. Nedveckyte, V. Dirginčiūtè-Volodkienè, and V. Būda. 2010. Pine defoliator Bupalus piniaria L. (Lepidoptera: Geometridae) and its entomopathogenic fungi. 1. Fungi isolation and testing on larvae. Ekologija 56:34-40.

Rodas, D. B. 2006. The use of botanical feed additives in nursery and sow diets in the US. In: Proceedings of Delacon Performing Nature Symposium. Vienna, Austria. pp. 1-4.

SAS. 2003. SAS version 9.1. SAS Institude Inc Cary NC, USA.

Savage, A. W. J., P. D. Warriss, and P. D. Jolley. 1990. The amount and composition of the proteins in drip from stored pig meat. Meat Sci. 27:289-303.

Schone, F., A. Vetter, H. Hartung, H. Bergmann, A. Biertumpfel, G. Richter, S. Muller, and G. Breitschuh. 2006. Effects of essential oils from fennel (Foeniculi aetheroleum) and caraway (Carvi aetheroleum) in pigs. J. Anim. Physiol. Anim. Nutr. 90:500-510.

Shi, Y. H., Z. R. Xu, J. L. Feng, M. S. Xia, and C. H. Hu. 2005. Effects of modified montmorillonite nanocomposite on growing/finishing pigs during aflatoxicosis. Asian Austalas. J. Anim. Sci. 18:1305-1309.

Terlouw, C. 2005. Stress reactions at slaughter and meat quality in pigs: genetic background and prior experience: A brief review of recent findings. Livest. Prod. Sci. 94:125-135.

Thiex, N. J., H. Manson, S. Anderson, and J. Persson. 2002. Determination of crude protein in animal feed, forage, grain, and oilseeds by using block digestion with a copper catalyst and steam distillation into boric acid: collaborative study. J. AOAC Int. 85:309-317.

Thiex, N. J., S. Anderson, and B. Gildemeister. 2003. Crude fat, diethyl ether extraction, in feed, cereal grain, and forage (Randall/Soxtec/submersion method): Collaborative study. J. AOAC Int. 86:888-898.

Van Krimpen, M. M., G. P. Binnendijk, F. H. M. Borgsteede, and C. P. H. Gaasenbeek. 2010. Anthelmintic effects of phytogenic feed additives in Ascaris suum inoculated pigs. Vet. Parasitol. 168:269-277.

Van Soest, P. J., J. B. Robertson, and B. A. Lewis. 1991. Methods for dietary fiber, neutral detergent fiber, and nonstarch polysaccharides in relation to animal nutrition. J. Dairy Sci. 74:3583-3597.

Wang, J. P., H. J. Kim, Y. J. Chen, J. S. Yoo, J. H. Cho, D. K. Kang, Y. Hyun, and I. H. Kim. 2009. Effects of delta-aminolevulinic acid and vitamin $\mathrm{C}$ supplementation on feed intake, backfat, and iron status in sows. J. Anim. Sci. 87:3589-3595.

Wang, Q., H. J. Kim, J. H. Cho, Y. J. Chen, J. S. Yoo, B. J. Min, Y. Wang, and I. H. Kim. 2008. Effects of phytogenic substances on growth performance, digestibility of nutrients, faecal noxious gas content, blood and milk characteristics and reproduction in sows and litter performance. J. Anim. Feed Sci. 17:50-60.

Wang, Y., Y. J. Chen, J. H. Cho, J. S. Yoo, Q. Wang, Y. Huang, H. J. Kim, and I. H. Kim. 2007. The effects of dietary herbs and coral mineral complex on growth performance, nutrient digestibility, blood characteristics and meat quality in finishing pigs. J. Anim. Feed Sci. 16:397-407.

Wenk, C. 2003. Herbs and botanicals as feed additives in monogastric animals. Asian Austalas. J. Anim. Sci. 16:282-289.

Windisch, W., K. Schedle, C. Plitzner, and A. Kroismayr. 2008. Use of phytogenic products as feed additives for swine and poultry. J. Anim. Sci. 86:E140-E148.

Williams, P. and R. Losa. 2001. The use of essential oils and their compounds in poultry nutrition. World Poult. 17:14-15.

Yan, L., J. P. Wang, H. J. Kim, Q. W. Meng, X. Ao, S. M. Hong, and I. H. Kim. 2010. Influence of essential oil supplementation and diets with different nutrient densities on growth performance, nutrient digestibility, blood characteristics, meat quality and fecal noxious gas content in grower-finisher pigs. Livest. Sci. 128:115-122.

Yan, L., Q. W. Meng, and I. H. Kim. 2011a. The effects of dietary Houttuynia cordata and Taraxacum officinale extract powder on growth performance, nutrient digestibility, blood characteristics and meat quality in finishing pigs. Livest. Sci. 141:188-193.

Yan, L., Q. W. Meng, and I. H. Kim. 2011b. The effect of an herb extract mixture on growth performance, nutrient digestibility, blood characteristics and fecal noxious gas content in growing pigs. Livest. Sci. 141:143-147. 
Zhang, S., J. H. Jung, H. S. Kim, B. Y. Kim, and I. H. Kim. 2012. Influences of phytoncide supplementation on growth performance, nutrient digestibility, blood profiles, diarrhea scores and fecal microflora shedding in weaning pigs. Asian Austalas. J. Anim. Sci. 25:1309-1315.
Zhong, M., D. Wu, Y. Lin, and Z. F. Fang. 2011. Phytogenic feed additive for sows: Effects on sow feed intake, serum metabolite concentrations, igG level, lysozyme activity and milk quality. J. Agric. Sci. Technol. A1:802-810. 